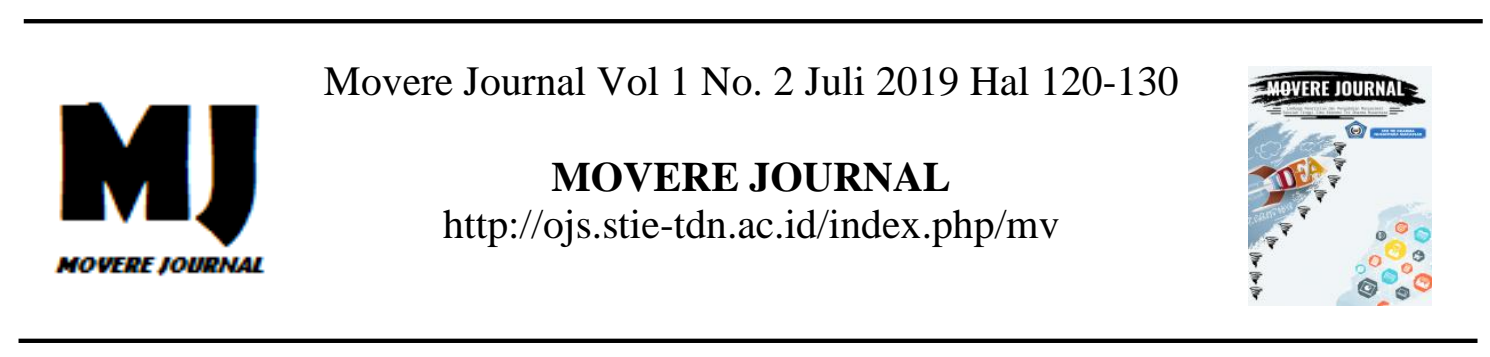

\title{
ANALISIS KINERJA KEUANGAN DAN PENGARUHNYA TERHADAP NILAI PERUSAHAAN PADA SEKTOR INFRASTUKTUR UTILITAS DAN TRANSPORTASI DI BURSA EFEK INDONESIA
}

\author{
Andi Hendro \\ STIE Tri Dharma Nusantara
}

\begin{abstract}
Abstrak : Penelitian ini bertujuan untuk menguji pengaruh Debt to Equity Ratio (DER), Earning Per Share (EPS) dan Net Profit Margin (NPM) terhadap nilai perusahaan (Tobin's Q), secara simultan maupun parsial. Metode penelitian asosiatif dengan teknis analisis linier berganda. Teknik analisis yang digunakan adalah uji asumsi klasik, uji hipotesis dan regresi linear berganda. Hasil penelitian ini menunjukkan bahwa secara simultan Debt to Equity Ratio, Earning per Share Dan Net Profit Margin berpengaruh signifikan terhadap nilai perusahaan. Debt to Equity Ratio dan Net Profit Margin berpengaruh signifikan secara parsial terhadap nilai perusahaan serta memberikan kontribusi yang cukup besar terhadap nilai perusahaan pada sektor infrastruktur, utilitas dan transportasi di Bursa Efek Indonesia, maka manajemen perusahaan infrastruktur, utilitas dan transportasi sebaiknya memperhatikan nilainilai Debt to Equity Ratio dan Net Profit Margin yang akan berpengaruh pada nilai perusahaan, sedangkan Earning per Share tidak berpengaruh terhadap nilai perusahaan pada sektor infrastruktur, utilitas dan transportasi di Bursa Efek Indonesia.
\end{abstract}

Kata kunci: kinerja keuangan, nilai perusahaan

\section{PENDAHULUAN}

Perusahaan memiliki tujuan jangka pendek dan jangka panjang. Dalam jangka pendek perusahaan bertujuan memperoleh laba secara maksimal dengan menggunakan sumber daya yang ada. Sementara dalam jangka panjang tujuan utama perusahaan adalah memaksimalkan nilai perusahaan. Nilai perusahaan akan tergambar dari harga saham perusahaan yang bersangkutan. Nilai perusahaan yang tinggi menunjukkan kemakmuran pemegang saham juga tinggi. Untuk itu pemilik dari suatu perusahaan mempercayakan perusahaannya kepada manajer. Memaksimukan nilai perusahaan merupakan salah satu tugas dari manajer keuangan. Nilai perusahaan yang maksimal merupakan hasil penentuan dari struktur modal yang optimal. Dimana penggunaan hutang perusahaan dapat memaksimumkan nilai perusahaan.

Nilai perusahaan merupakan nilai gabungan dari nilai pasar dari saham yang diterbitkan dan nilai pasar hutang dari suatu perusahaan. Nilai perusahaan merupakan nilai pasar atas surat berharga hutang dan ekuitas perusahaan yang beredar, (Keown, 2004:116). Nilai perusahaan dapat dilihat dari kemampuan perusahaan membayar dividen. Besarnya dividen dapat mempengaruhi harga saham. Apabila dividen yang dibayarkan tinggi maka harga dividen yang dibayarkan kepada pemegang saham kecil maka harga saham perusahaan yang membagikannya tersebut juga rendah. Dengan dividen 
yang besar akan meningkatkan nilai perusahaan. Nilai perusahaan merupakan persepsi investor terhadap tingkat keberhasilan perusahaan yang sering dikaitkan dengan harga saham. Harga saham yang tinggi membuat nilai perusahaan juga tinggi.

Sehingga penelitian ini akan melanjutkan penelitian terdahulu yang telah meneliti faktor-faktor yang memengaruhi nilai perusahaan, khususnya perusahaan-perusahaan yang emiten di Bursa Efek Indonesia sektor Infrastruktur, Utilitas dan Transportasi.

\section{TELAAH LITERATUR DAN PENGEMBANGAN HIPOTESIS}

Beberapa faktor yang dapat menentukan nilai perusahaan antara lain debt to equity ratio, earning per share dan net profit margin. Ketiga faktor tersebut mampu mempengaruhi penurunan atau peningkatan nilai suatu perusahaan.

Debt to Equity Ratio (DER) adalah rasio yang digunakan untuk mengukur hutang yang digunakan suatu perusahaan berbanding dengan modal sendiri. Semakin tinggi rasio DER maka penggunaan hutang dari pada modal sendiri akan semakin tinggi.

Earning Per Share atau laba per lembar saham merupakan salah satu rasio pasar untuk mengukur seberapa besar pendapatan untuk setiap saham yang telah beredar. Perusahaan dapat dikatakan mampu memaksimalkan nilai perusahaan jika laba per lembar saham yang mereka peroleh terus meningkat. Dengan EPS yang tinggi maka menunjukkan kinerja perusahaan semakin baik. EPS yang semakin meningkat dapat menunjukkan prospek perusahaan dimasa yang akan datang.

Rasio Net Profit Margin untuk mengukur kemampuan perusahaan dalam memperoleh laba bersih digunakan untuk mengukur profitabilitas suatu perusahaan.
Net Profit Margin merupakan perbandingan antara laba bersih dengan penjualan. Semakin tinggi rasio tersebut maka kemampuan memperoleh laba oleh perusahaan akan semakin besar.

Sedangkan berdasarkan penelitian terdahulu dapat dideskripsikan sebagai berikut, Telepta (2011) meneliti tentang pengaruh kinerja keuangan terhadap nilai perusahaan. Metode penelitian yang digunakan yaitu analisis regresi linear berganda. Tujuan penelitian ini untuk memperoleh bukti empiris tentang kinerja keuangan terhadap nilai perusahaan. Hasil penelitian menunjukkan bahwa Return On Asset (ROA) berpengaruh terhadap nilai perusahaan (Tobin's q), Earning Per Share (EPS) berpengaruh signifikan terhadap nilai perusahaan, sedangkan Return On Equity tidak berpengaruh terhadap nilai perusahaan.

Ratih (2011) meneliti tentang pengaruh good corporate governance terhadap nilai perusahaan. Metode penelitian yang digunakan adalah analisis structural equation model. Tujuan penelitian ini untuk menguji pengaruh Good Corporate Governance terhadap nilai perusahaan dengan menggunakan variabel intervening yaitu NPM dan ROA. Good Corporate Governance berpengaruh terhadap nilai perusahaan dengan Net Profit Margin sebagai variabel intervening.

Ogolmagai (2013) meneliti tentang pengaruh leverage terhadap nilai perusahaan. Metode penelitian yang digunakan yaitu analisis regresi linear berganda. Tujuan penelitian ini untuk mengetahui struktur modal yang di ukur dengan menggunakan Debt to Equity Ratio (DER) terhadap nilai perusahaan manufaktur yang go publik di Indonesia.

Irayanti (2014) meneliti tentang pengaruh kinerja keuangan terhadap nilai perusahaan pada industri makanan dan minuman di BEI. Metode penelitian yang digunakan yaitu analisis regresi linear berganda. Penelitian ini bertujuan untuk 
menguji pengaruh Debt to Equity Ratio (DER), Earning Per Share (EPS) dan Net Profit Margin (NPM) terhadap nilai perusahaan (Tobin's q), secara simultan maupun parsial. Hasil penelitian ini menunjukkan bahwa baik secara simultan maupun parsial debt to equity ratio, earning per share dan net profit margin berpengaruh signifikan terhadap nilai perusahaan. Debt to equity ratio, earning per share dan net profit margin memiliki pengaruh serta memberikan kontribusi yang cukup besar terhadap nilai perusahaan.

\section{Perumusan Masalah}

Berdasarkan latar belakang serta tinjauan pustaka khususnya bukti empiris dari penelitian-penelitian terdahulu yang mengemukakan fenomena gap atau research gap terhadap inkonsistensi faktor-faktor yang memengaruhi nilai perusahaan sehingga penelitian lanjutan ini mengajukan kerangka konseptual dan pertanyaan penelitian sebagai berikut :

\section{Kerangka Konseptual}

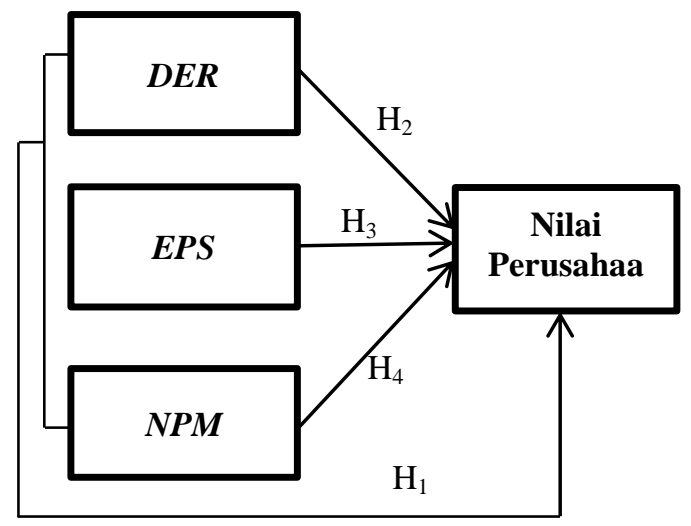

Gambar 1. Kerangka Penelitian

Sumber: Kajian Teori 2019

1. Apakah DER, EPS dan NPM berpengaruh secara simultan terhadap nilai perusahaan pada sektor infrastruktur, utilitas dan transportasi yang terdaftar di Bursa Efek Indonesia?
2. Apakah DER secara parsial berpengaruh terhadap nilai perusahaan pada sektor infrastruktur, utilitas dan transportasi yang terdaftar di Bursa Efek Indonesia?

3. Apakah EPS secara parsial berpengaruh terhadap nilai perusahaan pada sektor infrastruktur, utilitas dan transportasi yang terdaftar di Bursa Efek Indonesia?

4. Apakah NPM secara parsial terhadap nilai perusahaan pada sektor infrastruktur, utilitas dan transportasi yang terdaftar di Bursa Efek Indonesia?

\section{Tujuan Penelitian}

Penelitian ini bertujuan untuk mengetahui pengaruh:

1. DER, EPS dan NPM secara simultan terhadap nilai perusahaan pada sektor infrastruktur, utilitas dan transportasi yang terdaftar di Bursa Efek Indonesia.

2. DER secara parsial terhadap nilai perusahaan pada sektor infrastruktur, utilitas dan transportasi yang terdaftar di Bursa Efek Indonesia.

3. EPS secara parsial terhadap nilai perusahaan pada sektor infrastruktur, utilitas dan transportasi yang terdaftar di Bursa Efek Indonesia.

4. NPM secara parsial terhadap nilai perusahaan pada sektor infrastruktur, utilitas dan transportasi yang terdaftar di Bursa Efek Indonesia.

\section{Hipotesis Penelitian}

Berdasarkan teori dan kajian empiris serta rumusan masalah yang telah dikemukakan maka hipotesis yang dirumuskan dalam penelitian ini sebagai berikut :

$$
\begin{aligned}
\mathrm{H} 1= & \text { Debt to Equity Ratio, Earning per } \\
& \text { Share dan Net Profit Margin } \\
& \text { secara simultan berpengaruh } \\
& \text { terhadap nilai perusahaan pada } \\
& \text { sektor infrastruktur, utilitas dan } \\
& \text { transportasi yang terdaftar di }
\end{aligned}
$$


Bursa Efek Indonesia tahun 2013 $-2017$.

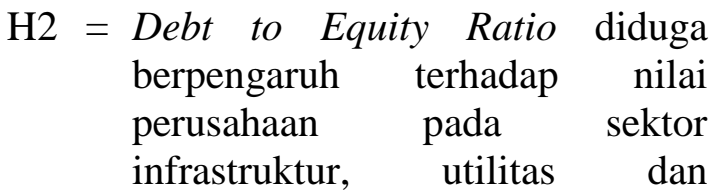
transportasi yang terdaftar di Bursa Efek Indonesia tahun 2013 $-2017$.

H3 = Earning Per Share diduga berpengaruh terhadap nilai perusahaan pada sektor infrastruktur, utilitas dan transportasi yang terdaftar di Bursa Efek Indonesia tahun 2013 $-2017$.

$\mathrm{H} 4=$ Net Profit Margin diduga berpengaruh terhadap nilai perusahaan pada sektor infrastruktur, utilitas dan transportasi yang terdaftar di Bursa Efek Indonesia tahun 2013 $-2017$.

\section{Nilai Perusahaan}

Husnan (2000:7) menyatakan nilai perusahaan merupakan nilai pasar atas surat berharga hutang dan ekuitas perusahaan yang beredar. Nilai perusahaan yang tinggi menjadi keinginan para pemilik perusahaan, sebab dengan nilai yang tinggi menunjukkan kemakmuran pemegang saham juga tinggi. Kekayaan pemegang saham dan perusahaan dipresentasikan oleh harga pasar dari saham yang merupakan cerminan dari keputusan investasi pendanaan dan manajemen asset Susanti (2010) dalam Mahendra (2011:18). Nilai perusahaan (Tobin's q) dapat dihitung dengan rumus sebagai berikut:

$$
\text { Tobin's } Q=\frac{\text { Nilai pasar saham biasa }+ \text { Nilai buku hutang }}{\text { Total Aset }}
$$

\section{Debt to Equity Ratio}

Brigham dan Houston (2006:306)

Debt to Equity Ratio (DER) merupakan perbandingan antara total hutang dengan total modal sendiri (ekuitas). Makin tinggi Debt to Equity Ratio maka akan menunjukkan semakin besarnya modal pinjaman yang digunakan untuk pembiayaan aktiva perusahaan. Semakin tinggi Debt to Equity Ratio, maka semakin berisiko bagi perusahaan (kemungkinan perusahaan tidak dapat membayar semua hutangnya). Rumus untuk mencari debt to equity ratio sebagai berikut:

$$
D E R=\frac{\text { Total Hutang }}{\text { Modal Sendiri }}
$$

\section{Earning per Share}

Tjiptono dan Hendry (2001:139) menyatakan earning per share merupakan rasio yang menunjukkan berapa besarnya keuntungan yang diperoleh investor atau pemegang saham per lembar saham. Rumus EPS sebagai berikut:

$$
E P S=\frac{\text { Laba Bersih }}{\text { Jumlah saham yang beredar }}
$$

\section{Net Profit Margin}

Suwardjono (2006:18) Net Profit Margin (NPM) adalah rasio yang digunakan untuk menunjukkan kemampuan perusahaan dalam menghasilkan keuntungan bersih. Net Profit Margin adalah perbandingan antara laba bersih dengan penjualan. Rumus NPM sebagai berikut:

$$
N P M=\frac{\text { Laba Bersih }}{\text { Penjualan }}
$$

\section{METODE PENELITIAN}

\section{Jenis Penelitian}

Jenis penelitian yang digunakan dalam penelitian ini adalah asosiatif dimana penelitian ini bertujuan untuk menguji hipotesis dan merupakan penelitian yang menjelaskan fenomena dalam bentuk hubungan antar variabel.

\section{Tempat Penelitian}

Lokasi penelitian ini pada perusahaan sektor infrastruktur, utilitas 
dan transportasi yang go public di Bursa Efek Indonesia (BEI) dengan cara mengunjungi www.idx.co.id.

\section{Metode Pengumpulan Data}

Data yang digunakan dalam penelitian ini adalah data sekunder, yaitu berdasarkan pada laporan keuangan yang dipublikasikan oleh Bursa Efek Indonesia periode 2013 sampai dengan 2017.

\section{Populasi dan Sampel}

Populasi dalam penelitian ini adalah seluruh perusahaan sektor infrastruktur, utilitas dan transportasi yang terdafar di Bursa Efek Indonesia 2013-2017 sebanyak 41 perusahaan. Sampel pada penelitian ini diambil dengan menggunakan metode Purposive Sampling. Purposive Sampling merupakan teknik penentuan sampel dengan prtimbangan khusus sehingga layak dijadikan sampel (Supriyadi, 2014:22). Perusahaan yang melakukan IPO (Initial Public Offering) ataupun delisting selama periode penelitian dan perusahaan yang tidak memiliki laporan keuangan yang lengkap, yang mengalami kerugian serta memiliki ekuitas yang negatif tidak dimasukkan dalam penelitian ini. Dengan metode purposive sampling, sampel dalam penelitian ini sebanyak 15 perusahaan.

\section{Metode Analisis}

Metode analisis data yang digunakan dalam penelitian ini adalah teknik analisis kuantitatif, yang merupakan suatu teknik analisa data yang menggunakan angka-angka sebagai datanya dan analisis menggunakan statistik agar pemecahan masalah dapat dihitung secara pasti (Supriyadi, 2014:7) Alat analisis yang digunakan adalah regresi linear berganda yang menghasilkan nilai koefisien determinasi dan model persamaan regresi linear berganda.

\section{Teknik Pengolahan Data}

Dalam menggunakan analisis regresi linear berganda, agar persamaan regresi tersebut layak digunakan atau diaplikasikan, maka harus ada beberapa asumsi yang harus dipenuhi antara lain terdiri dari uji autokorelasi, uji multikolinearitas, uji heteroskedastisitas dan uji normalitas (Supriyadi, 2014:71).

Sedangkan metode analisis dalam memprediksi struktur modal dilakukan dengan metode analisis regresi linear berganda (multiple regression). Metode regresi linear berganda digunakan untuk menguji pengaruh lebih dari satu variabel independen terhadap variabel dependen (Supriyadi, 2014:66). Adapun model regresi berganda dalam penelitian ini adalah sebagai berikut:

$$
\mathbf{Y}=\boldsymbol{\beta}_{0}+\boldsymbol{\beta}_{1} \mathbf{X}_{1}+\boldsymbol{\beta}_{2} \mathbf{X}_{2}+\boldsymbol{\beta}_{2} \mathbf{X}_{2}+\varepsilon
$$

\section{HASIL PENELITIAN DAN PEMBAHASAN}

\section{Hasil Penelitian}

Hasil Uji Multikolinieritas

Tabel 1. Hasil Uji Multikolinieritas

\begin{tabular}{lcc}
\hline Model & \multicolumn{2}{c}{ Collinearity Statistic } \\
\cline { 2 - 3 } & Tolerance & VIF \\
\hline (Constan) & & \\
Debt to Equity Ratio & 0,992 & 1,008 \\
Earning Per Share & 0,998 & 1,013 \\
Net Profit Margin & 0,980 & 1,020 \\
\hline
\end{tabular}

Sumber : Hasil Olahan Data 2019

Tabel 1 diatas menunjukkan hasil perhitungan VIF, dapat ditarik kesimpulan bahwamodel tidak terjadi multikolinearitas antar variabel independen karena nilai VIF masingmasing lebih kecil dari 10 . 


\section{Hasil Uji Heteroskesdastisidas}

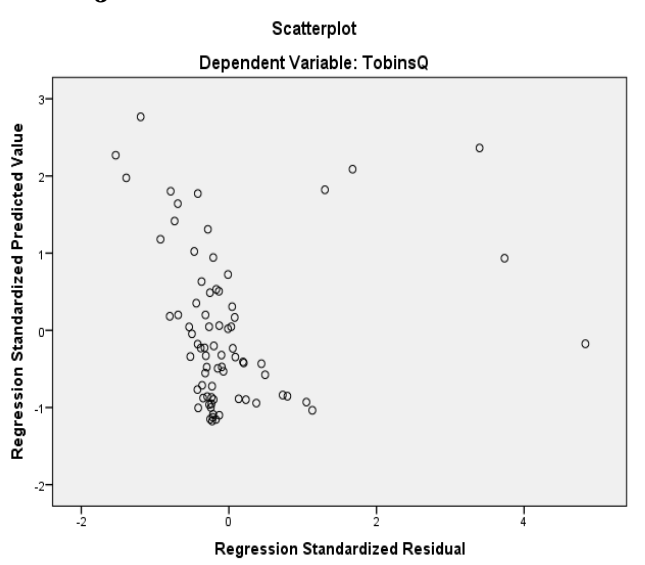

Gambar 2. Uji Asumsi Klasik Heteroskesdastis

Sumber: Hasil Olahan Data 2019

Gambar 2 diatas menunjukkan grafik Scatterplot yang ditampilkan untuk uji heterokesdastisitas menampakkan titik-titik yang menyebar secara acak dan tidak ada pola yang jelas terbentuk serta dalam penyebaran titik-titik tersebut menyebar dibawah dan diatas angka 0 pada sumbu Y. Hal tersebut mengidentifikasikan tidak terjadinya heterokesdastisitas pada model regresi, sehingga model regresi Debt to Equity Ratio $\left(\mathrm{X}_{1}\right)$, Earning per Share $\left(\mathrm{X}_{2}\right)$, Net Profit Margin $\left(\mathrm{X}_{3}\right)$ layak dipakai untuk memprediksi variabel Nilai Perusahaan(Y).

\section{Uji Normalitas}

Gambar 3 menunjukkan bahwa grafik Normal P-P Plot of Regression Standardized Residual menggambarkan penyebaran data di sekitar garis diagonal dan penyebarannya mengikuti arah garis diagonal grafik tersebut, maka model regresi Pengaruh Debt to Equity Ratio $\left(\mathrm{X}_{1}\right)$, Earning per Share $\left(\mathrm{X}_{2}\right)$, Net Profit $\operatorname{Margin}\left(\mathrm{X}_{3}\right)$ Terhadap Nilai Perusahaan (Y) yang digunakan dalam penelitian ini memenuhi asumsi normalitas.

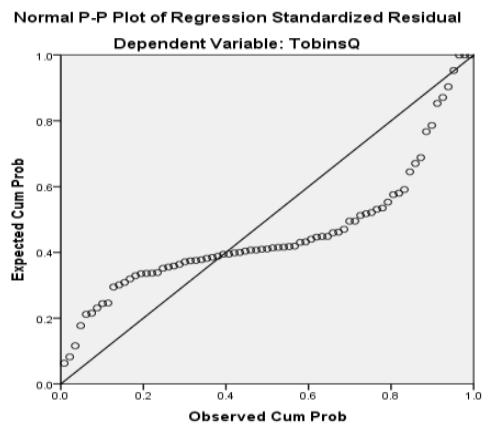

Gambar 3. Uji Asumsi Klasik Normalitas

Sumber: Hasil Olahan Data 2014

Analisis Regresi Linear Berganda

Tabel 2. Regresi Linear Berganda

\begin{tabular}{lcc}
\hline Model & \multicolumn{2}{c}{ Unstandardized Coefficients } \\
\cline { 2 - 3 } & $\mathrm{B}$ & Std. Error \\
\hline (Constan) & 1,123 & 0,472 \\
$D E R$ & 0,002 & 0,001 \\
$E P S$ & 0,037 & 0,108 \\
NPM & 0,038 & 0,016 \\
\hline
\end{tabular}

Sumber : Hasil Olahan Data 2019

Dari hasil tabel di atas, maka didapat persamaan regresi linier berganda sebagai berikut :

$$
\begin{gathered}
Y=1,123+0,002 X_{1}+0,037 X_{2}+0,038 X_{3} \\
+\varepsilon
\end{gathered}
$$

Model regresi $\mathrm{Y}=1,123+$ $0,002 \mathrm{X}_{1}+0,037 \mathrm{X}_{2}+0,038 \mathrm{X}_{3}$ $+\varepsilon$ menggambarkan bahwa variabel bebas (independen) Debt to Equity Ratio $\left(\mathrm{X}_{1}\right)$, Earning per Share $\left(\mathrm{X}_{2}\right)$, Net Profit Margin $\left(\mathrm{X}_{3}\right)$ dalam model regresi tersebut dapat dinyatakan jika satu variabel independen berubah sebesar 1 (satu) dan lainnya konstan, maka perubahan variabel terikat (dependen) Nilai perusahaan (Y) adalah sebesar nilai koefisien ( $\beta)$ dari nilai variabel independen tersebut.

Konstanta $(\alpha)$ sebesar 1,123 memberikan pengertian bahwa jika Debt to Equity Ratio $\left(\mathrm{X}_{1}\right)$, Earning per Share $\left(\mathrm{X}_{2}\right)$, Net Profit Margin $\left(\mathrm{X}_{3}\right)$ secara serempak atau bersama-sama tidak mengalami perubahan atau sama dengan nol(0) maka besarnya Nilai Perusahaan (C) 2019 STIE TDN. All rights reserved 
(Y) sebesar 1,123 satuan. Jika nilai $\beta_{1}$ yang merupakan koefisien korelasi dari Debt to Equity Ratio $\left(\mathrm{X}_{1}\right)$ sebesar 0.002 yang artinya mempunyai pengaruh positif terhadap variabel dependen (Y) mempunyai arti bahwa jika variabel Debt to Equity Ratio $\left(\mathrm{X}_{1}\right)$ bertambah 1 satuan, maka Nilai Perusahaan (Y) juga akan mengalami kenaikkan sebesar 0.002 satuan dengan asumsi variabel lain tetap atau konstan.

Nilai $\beta_{2}$ yang merupakan koefisien korelasi dari Earning per Share $\left(\mathrm{X}_{2}\right)$ sebesar 0,037 yang artinya mempunyai pengaruh positif terhadap variabel dependen (Y) mempunyai arti bahwa jika variabel Earning per Share $\left(\mathrm{X}_{2}\right)$ bertambah 1 satuan, maka Nilai Perusahaan (Y) akan mengalami kenaikkan sebesar 0,037 satuan dengan asumsi variabel lain tetap atau konstan.

Jika nilai $\beta_{3}$ yang merupakan koefisien korelasi dari Net Profit Margin $\left(\mathrm{X}_{3}\right)$ sebesar 0,038 yang artinya mempunyai pengaruh positif terhadap variabel dependen (Y) mempunyai arti bahwa jika variabel Net Profit Margin $\left(\mathrm{X}_{3}\right)$ bertambah 1 satuan, maka Nilai Perusahaan (Y) akan mengalami kenaikan sebesar 0,038 satuan dengan asumsi variabel lain tetap atau konstan.

Tabel 3. Hubungan Antar Variabel

\begin{tabular}{ccccc}
\hline Model & $\mathbf{R}$ & $\begin{array}{c}\mathbf{R} \\
\text { Square }\end{array}$ & $\begin{array}{c}\text { Adjusted } \\
\mathbf{R} \\
\text { Square }\end{array}$ & $\begin{array}{r}\text { Std. Error } \\
\text { of The } \\
\text { Estimate }\end{array}$ \\
\hline 1 & 0,362 & 0,131 & 0,94 & 2,24170 \\
\hline \multicolumn{4}{l}{ Sumber : Hasil Olahan Data 2019}
\end{tabular}

Berdasarkan hasil perhitungan dengan menggunakan bantuan program SPSS 21.0 seperti yang ada pada tabel diatas dapat dilihat bahwa nilai $(\mathrm{R})$ yang dihasilkan antara pengaruh Debt to Equity Ratio $\left(\mathrm{X}_{1}\right)$, Earning per Share $\left(\mathrm{X}_{2}\right)$, Net Profit Margin $\left(\mathrm{X}_{3}\right)$ Terhadap Nilai Perusahaan(Y) adalah sebesar 0,362 atau $36,2 \%$. Artinya hubungan Debt to Equity Ratio $\left(\mathrm{X}_{1}\right)$, Earning per Share $\left(\mathrm{X}_{2}\right)$, Net Profit Margin $\left(\mathrm{X}_{3}\right)$ mempunyai hubungan yang kurang kuat dengan Nilai Perusahaan (Y).

Koefisien determinasi $\left(\mathrm{R}^{2}\right)$ diperlukan untuk mengukur seberapa besar pengaruh variabel $\mathrm{X}$ terhadap variabel Y. Nilai Koefisien determinasi $\left(\mathrm{R}^{2}\right)$ adalah sebesar 0,131 ini memberikan pengertian bahwa besarnya Nilai Perusahaan (Y) dapat dijelaskan oleh variabel independen yaitu Debt to Equity Ratio $\left(\mathrm{X}_{1}\right)$, Earning per Share $\left(\mathrm{X}_{2}\right)$, dan Net Profit Margin $\left(\mathrm{X}_{3}\right)$ adalah hanya sebesar $13,1 \%$ sementara sisanya $86,9 \%$ dijelaskan oleh variabel lain yang tidak diteliti dalam penelitian ini.

\section{Pengujian Hipotesis}

Perumusan hipotesis yang diuji telah dikemukakan dalam uraian sebelumnya dengan tingkat signifikansi yang digunakan dalam penelitian ini sebesar 5\% atau $\alpha=0,05$ maka hasil pengujian hipotesis tersebut adalah sebagai berikut :

\section{Uji F}

Pada tabel dibawah ini dapat dilihat uji $F$ untuk menguji semua variabel bebas pengaruh Debt to Equity Ratio $\left(\mathrm{X}_{1}\right)$, Earning per Share $\left(\mathrm{X}_{2}\right)$, Net Profit Margin $\left(\mathrm{X}_{3}\right)$ yang akan mempengaruhi variabel Nilai Perusahaan (Y).

Tabel 4. Hubungan Linear Antara Variabel Bebas Dengan Tidak Bebas

\begin{tabular}{|c|c|c|c|c|c|c|}
\hline & Model & $\begin{array}{c}\text { Sum of } \\
\text { Squares }\end{array}$ & df & $\begin{array}{c}\text { Mean } \\
\text { Square }\end{array}$ & $\mathbf{F}$ & Sig. \\
\hline \multirow{3}{*}{1} & Regression & 53,884 & 3 & 17,961 & 3,574 & 0,018 \\
\hline & Residual & 356,791 & 71 & 5,025 & & \\
\hline & Total & 410,676 & 74 & & & \\
\hline
\end{tabular}

Sumber : Hasil Olahan Data 2019

Hasil analisis regresi menggunakan SPSS 21.0 didapatkan $\mathrm{F}_{\text {hitung }}=3,574>2,70$ dengan tingkat signifikan $\mathrm{p}$-value $=0,018<0,05$, maka dapat disimpulkan bahwa $\mathrm{HO}$ ditolak atau Ha diterima yang berarti bahwa Debt to Equity Ratio (X1), Earning per Share (X2), Net Profit Margin (X3) secara 
simultan berpengaruh signifikan terhadap Nilai Perusahaan (Y).

\section{Uji t}

Uji $\mathrm{t}$ digunakan untuk menguji signifikansi pengaruh variabel independen terhadap variabel dependen dalam model regresi yang sudah dihasilkan.Maka digunakan uji t untuk menguji masing-masing variabel independen terhadap variabel dependen.

Tabel 5. Hasil Analisis Regresi

\begin{tabular}{llcc}
\hline Model & t & Sig \\
\hline 1 & (Constant) & 2,378 & 0,020 \\
& DER & 1,889 & 0,043 \\
& EPS & 0,345 & 0,731 \\
& NPM & 2,424 & 0,018 \\
\hline
\end{tabular}

Sumber : Hasil Olahan Data 2019

Hasil uji t pada tabel diatas dapat dilihat bahwa Debt to Equity Ratio $\left(\mathrm{X}_{1}\right)$ $\mathrm{t}_{\text {hitung }}=1,889>1,669$ dan signifikansi $\mathrm{p}$ value $=0,043<0,05$, maka dapat disimpulkan bahwa $\mathrm{Ha}$ diterima dan menolak $\mathrm{H} 0$ atau Debt to Equity Ratio $\left(\mathrm{X}_{1}\right)$ berpengaruh signifikan terhadap Nilai Perusahaan(Y). Dari hasil uji t pada tabel diatas dapat dilihat bahwa Earning per Share $\left(\mathrm{X}_{2}\right) \mathrm{t}_{\text {hitung }}=0,345<$ 1,669 dan signifikansi $\mathrm{p}$-value $=0,731>$ 0,05, maka dapat disimpulkan bahwa $\mathrm{Ha}$ ditolak dan menerima $\mathrm{H} 0$ atau Earning per Share $\left(\mathrm{X}_{2}\right)$ tidak berpengaruh signifikan terhadap Nilai Perusahaan(Y). Dari hasil uji t pada tabel diatas dapat dilihat bahwa Net Profit $\operatorname{Margin}\left(\mathrm{X}_{3}\right)$ $\mathrm{t}_{\text {hitung }}=2,424>1,669$ dan signifikansi $\mathrm{p}$ value $=0,018<0,05$, maka dapat disimpulkan bahwa $\mathrm{Ha}$ diterima dan menolak H0 atau Net Profit Margin $\left(\mathrm{X}_{3}\right)$ berpengaruh signifikan terhadap Nilai Perusahaan(Y).

\section{Pembahasan}

Pengaruh Debt to Equity Ratio, Earning per Share dan Net Profit Margin terhadap Nilai Perusahaan

Hasil penelitian menunjukkan bahwa secara simultan Debt to Equity
Ratio, Earning per Share dan Net Profit Margin memiliki pengaruh yang signifikan terhadap Nilai Perusahaan. Hasil ini memperkuat hasil penelitian sebelumnya yaitu Irayanti (2014), dimana hasil penelitian tersebut menunjukkan bahwa secara simultan debt to equity ratio, earning per share dan net profit margin berpengaruh signifikan terhadap nilai perusahaan.

\section{Pengaruh Debt to Equity Ratio Terhadap Nilai Perusahaan}

Hasil penelitian menunjukkan bahwa Rasio DER mempunyai pengaruh positif yang signifikan. Hal tersebut menunjukkan bahwa setiap kenaikkan rasio DER maka nilai perusahaan akan meningkat dengan signifikan dan sebaliknya jika rasio DER menurun, yang berarti jika perusahaan mengurangi penggunaan hutang maka nilai perusahaan akan menurun. Hasil penelitian ini memperkuat penelitian sebelumnya yaitu penelitian Ogolmagai (2013), dimana disimpulkan bahwa Debt To Equity Ratio berpengaruh signifikan terhadap nilai perusahaan. Hal tersebut membuktikan bahwa rasio hutang mempengaruhi nilai perusahaan secara signifikan pada sektor utilitas, infrastruktur dan transportasi yang listing di Bursa Efek Indonesia periode 20152017.

\section{Pengaruh Earning Per Share Terhadap Nilai Perusahaan}

Hasil penelitian menunjukkan bahwa Earning Per Share memiliki pengaruh positif yang tidak signifikan. Hal ini berarti jika EPS mengalami kenaikkan atau penurunan maka nilai perusahaan tidak berpengaruh secara signifikan. Hasil penelitian ini bertolak belang dengan hasil penelitian sebelumnya yaitu Telelepta (2011), dimana disimpulkan bahwa Earning Per Share berpengaruh terhadap nilai perusahaan pada perusahaan manufaktur. 
Peningkatan laba per lembar saham yang diterima pemegang saham pada perusahaanperusahaan pada sektor utilitas, infrastruktur dan transportasi di Bursa Efek Indonesia tidak memengaruhi nilai perusahaan pada sektor utilitas, infrastruktur dan transportasi. Dengan kata lain, artinya naik turunnya EPS tidak akan memengaruhi naik turunnya nilai perusahaan.

\section{Pengaruh Net Profit Margin Terhadap Nilai Perusahaan}

Hasil penelitian menunjukkan bahwa rasio NPM mempunyai pengaruh positif yang signifikan. Artinya jika rasio NPM mengalami peningkatan yang berarti laba bersih yang diterima perusahaan meningkat maka nilai perusahaan pun akan mengalami peningkatan yang signifikan. Artinya peningkatan laba bersih yang diperoleh perusahaan telah mampu meningkatkan nilai perusahaan pada sektor utilitas, infrastruktur dan transportasi. Hasil penelitian ini memperkuat penelitian sebelumnya yaitu Ratih (2011), dimana profitabilitas berpengaruh signifikan terhadap nilai perusahaan. Hasil penelitian tersebut dapat disimpulkan bahwa penilaian prestasi suatu perusahaan dapat dilihat dari kemampuan perusahaan untuk menghasilkan laba.

\section{PENUTUP}

\section{Kesimpulan}

Kesimpulan dalam penelitian ini adalah sebagai berikut:

1. Kinerja keuangan yang meliputi Debt to Equity Ratio, Earning per Share, Net Profit Margin secara simultan berpengaruh signifikan terhadap Nilai Perusahaan pada sektor infrastruktur, utilitas dan transportasi di Bursa Efek Indonesia.

2. Debt to Equity Ratio secara parsial berpengaruh signifikan terhadap Nilai Perusahaan pada sektor infrastruktur, utilitas dan transportasi di Bursa Efek Indonesia.

3. Earning per Share secara parsial tidak berpengaruh signifikan terhadap Nilai Perusahaan pada sektor infrastruktur, utilitas dan transportasi di Bursa Efek Indonesia.

4. Net Profit Margin secara parsial berpengaruh signifikan terhadap Nilai Perusahaan pada sektor infrastruktur, utilitas dan transportasi di Bursa Efek Indonesia.

\section{Saran}

Saran dari penelitian ini adalah Debt to Equity Ratio dan Net Profit Margin memiliki pengaruh dan memberikan kontribusi yang cukup besar terhadap nilai perusahaan pada sektor infrastruktur, utilitas dan transportasi di Bursa Efek Indonesia maka manajemen perusahaan sebaiknya memperhatikan nilai-nilai Debt to Equity Ratio dan Net Profit Margin yang akan berpengaruh pada nilai perusahaan.

\section{DAFTAR PUSTAKA}

Brigham, E.F dan Houston, 2006. DasarDasar Manajemen Keuangan, Edisi Sepuluh, Alih Bahasa Ali Akbar Yulianto, Penerbit Salemba Empat. Jakarta.

D. Irayanti., A.L. Tumbel.2014. Analisis

Kinerja Keuangan Pengaruhnya Terhadap Nilai Perusahaan Pada Industri Makanan Dan Minuman Di Bei. Jurnal EMBA Vol.2 No.3 September 2014, Hal. 1473-1482. ISSN 2303-1174.

Husnan, S. 2000. Manajemen Keuangan Teori dan Penerapan (Keputusan Jangka Panjang). BPFE. Yogyakarta.

Keown, Arthur, 2004. Prinsip-Prinsip Dan Aplikasi Manajemen Keuangan. Penerbit Indeks, Jakarta. 
Mahendra. 2011. Pengaruh Kinerja

Keuangan Terhadap Nilai

Perusahaan (Kebijakan Dividen

Sebagai Variabel Moderating)

Pada Perusahaan Manufaktur di

Bursa Efek Indonesia. Skripsi.

Fakultas Ekonomi dan Bisnis

Universitas Diponegoro.

Semarang.

http//eprints.undip.ac.id/24067/1/

MAHENDRA.PDF. Diakses pada 20 Februari 2019. Hal.81-89.

Ogolmagai, Natalia. 2013. Leverage

Pengaruhnya Terhadap Nilai

Perusahaan Pada Industri

Manufaktur Yang Go Publik Di

Indonesia. Jurnal EMBA. ISSN

No 2302-1174.

http://ejournal.unsrat.ac.id/index.p

$\mathrm{hp} / \mathrm{emba} /$ article/view/2913/2464.

Diakses tanggal 20 Februari 2019.

Hal.81-89.

Ratih, Suklimah. 2011. Pengaruh Good Corporate Governance Terhadap Nilai perusahaan Dengan Kinerja Keuangan Sebagai Variabel Intervening Pada Perusahaan Peraih The Indonesia Most Trusted CompanyCG. Skripsi.
Fakultas Ekonomi dan Bisnis. Universitas Diponegoro. Semarang. http://eprints.undip. ac.id/35792/1/RATIH.pdf.

Diakses pada 22 Februari 2019. Hal 180.

Supriadi, Edy. 2014. SPSS + Amos. Penerbit In Media. Jakarta.

Suwardjono. 2006. Teori Akuntansi. Perekayasaan Pelaporan Keuangan.BPFE. Yogyakarta.

Telepta, Ilonna. 2011. Pengaruh Kinerja Keuangan Terhadap Nilai Perusahaan Pada Perusahaan Maufaktur Yang Terdaftar Di Bursa Efek Indonesia. Jurnal BISMA.

UniversitasGunadarma.Jakarta. http://ejournal.gunadarma.ac.idind ex.php/ekbis/articleview/880.

Diakses tanggal 24 Februari 2019. Hal 493-503.

Tjiptono, Darmadji dan Hendry $M$ Fakhruddin. 2001. Pasar Modal Di Indonesia. Salemba Empat. Jakarta. 